DOI https://doi.org/10.18551/rjoas.2020-11.20

\title{
COLLECTION OF FUNDS AND DISTRIBUTION OF PUBLIC FUND IN THE MIDDLE OF PANDEMI COVID-19 AT A BUMN BANK IN DENPASAR CITY
}

\author{
Putri Putu Yudha Asteria*, Martini Ni Putu Riski \\ University of Warmadewa, Indonesia \\ *E-mail: ydhasteria.putri@gmail.com
}

\begin{abstract}
The purpose of this study was to determine the policy of state-owned banks in Denpasar City in terms of collecting and distributing funds during the COVID 19 pandemic. This study uses a qualitative descriptive approach because this study aims to obtain an overview of the collection and distribution of funds at state-owned banks during a pandemic, which is described in form words (description). In addition, this study also observes state-owned banks with facts in the field which is carried out through direct interaction with them or observations in the field.
\end{abstract}

\section{KEY WORDS}

Fundraising, fund distribution, banking.

Today's national banking challenges are getting bigger and more complex. The national banking industry has experienced ups and downs of development since the last few decades. Especially now that Indonesia and other countries are experiencing the COVID-19 pandemic since December 2019. The COVID-19 pandemic has had a number of negative impacts on the world, especially Indonesia, which has been hit by the COVID-19 outbreak since March 2020. The impact caused by the spread of this virus has certainly been felt by many people, one of which is banking, an institution that is obliged to collect and distribute funds to the public. The President of the Republic of Indonesia, Joko Widodo said that public complaints as debtor customers do not need to worry about their installments, because interest payments or installments are given a leeway for 1 year (https://tirto.id/eJti). This statement makes people who have credit dependents can breathe easy, but on the other hand the banking and leasing industry is confused with this policy where the banking and OJK are not ready to undergo this credit suspension. It is also undeniable that many different perceptions have occurred and become chaotic between parties. As there are parties who think credit is really on hold for 1 year. Amid the frenzy of banking institutions reconstructing debtor credit payments, on the other hand Bank Indonesia (BI) guarantees that banking conditions will be safe amid the large impact of the corona virus pandemic, seen from the condition of capital or CAR and the ratio of non-performing loans or NPL which remains good compared to 2008 and 1997-1998. The industry's CAR currently reaches $23 \%$. Meanwhile, banking NPL before COVID-19 hit 2.5\% on a gross basis and $1.3 \%$ on a net basis. Under these conditions the banking industry still looks strong, although it is undeniable that there is a possibility that the financial industry will feel the pressure due to this pandemic. It is possible that state-owned banks can expand into sectors of the economy that are not affected by the outbreak.

In accordance with the Basic Banking Law No. 14 of 1967 which states that financial institutions have the main business of providing credit and services in payment traffic and circulation of money. The financial institution itself is a business entity that collects funds from the Bank in the form of deposits and distributes it to the public in the form of credit and or other forms in order to improve the people's standard of living. Fundraising is a fundraising activity, whether from individuals, organizations or legal entities. Fundraising includes the process of influencing the public to do good deeds in the form of handing over money (Rozalinda, 2015). In addition, Fundraising deals with the abilities of individuals, organizations, legal entities to invite and influence others so that it raises their awareness and concern. In this case, the institution needs to build fundraising ethics by referring to the 
mission of the institution (Abidah, 2016). Meanwhile, distribution of funds is to throw back funds obtained through current accounts, savings, and deposits to the public in the form of loans (credit) for banks based on conventional principles or financing for banks based on shari'ah principles. This activity of channeling funds is also known in banking as lending. In providing credit, in addition to being subject to interest, the bank also charges loan services to credit recipients (debtors) in the form of administrative fees as well as fees and commissions. (Hasanah, 2015) In this case, the institution needs to build fundraising ethics by referring to the mission of the institution (Abidah, 2016). Meanwhile, distribution of funds is to throw back funds obtained through current accounts, savings, and deposits to the public in the form of loans (credit) for banks based on conventional principles or financing for banks based on shari'ah principles. This activity of channeling funds is also known in banking as lending. In providing credit, in addition to being subject to interest, the bank also charges loan services to credit recipients (debtors) in the form of administrative fees as well as fees and commissions. (Hasanah, 2015) In this case, the institution needs to build fundraising ethics by referring to the mission of the institution (Abidah, 2016). Meanwhile, distribution of funds is to throw back funds obtained through current accounts, savings and deposits to the public in the form of loans (credit) for banks based on conventional principles or financing for banks based on shari'ah principles. This activity of channeling funds is also known in banking as lending. In providing credit, aside from being subject to interest, the bank also charges loan services to credit recipients (debtors) in the form of administrative fees and fees and commissions. (Hasanah, 2015) and deposits to the public in the form of loans (credit) for banks based on conventional principles or financing for banks based on shari'ah principles. This activity of channeling funds is also known in banking as lending. In providing credit, in addition to being subject to interest, the bank also charges loan services to credit recipients (debtors) in the form of administrative fees as well as fees and commissions. (Hasanah, 2015) and deposits to the public in the form of loans (credit) for banks based on conventional principles or financing for banks based on shari'ah principles. This activity of channeling funds is also known in banking as lending. In providing credit, aside from being subject to interest, the bank also charges loan services to credit recipients (debtors) in the form of administrative fees and fees and commissions. (Hasanah, 2015)

State-owned commercial banks (BUMN) have the largest number of debtor customers among other private banks. There are four state-owned banks located in Denpasar City, including Bank Rakyat Indonesia, Tbk., Bank Mandiri, Bank Negara Indonesia and Bank Tabungan Negara that have provided relief for debtors affected by the COVID-19 pandemic. The BUMN Bank has offered relief (restructuring) to debtor customers in the form of postponement of payment of obligations, such relief is provided in several forms according to the conditions of the debtor and / or the debtor's business so that it is easier and less burdensome for the debtor customer. Banking in Indonesia, which is based on economic democracy, with the main function of collecting the distribution of society, has a strategic role to support the implementation of national development in the context of increasing equitable distribution of development results, national stability economic growth towards improving the standard of living of the people at large. In this regard, banking service delivery is one of the objectives which is expected to fulfill the intended strategic role. However, with the COVID-19 pandemic, there is also the possibility of a financial performance crisis, especially in the banking sector.

Other research on the collection and distribution of funds conducted by Hidayat, et al. (2012) examined the collection and distribution of funds at the Manda Unit of Bank Rakyat Indonesia, this study was limited to obtaining information about the accounting cycle including the processes of recording, grouping, summarizing and reporting, as well as analyzing. . In addition, Debotman (2016), Saib (2016) and Afriyeni (2018) examined the differences in the collection and distribution of funds in commercial banks and Islamic banks. Research on the collection and distribution of bank funds is limited to the perspective of banking institutions. In the future, this research will also look not only from a banking perspective, but also from the public as a customer who has an important role for banking institutions to carry out their activities. Based on this background, it is necessary to conduct 
research on "Fundraising and Distribution of Public Funds in the Middle of the COVID-19 Pandemic at State-Owned Banks in Denpasar City". The formulation of the problem in this study is as follows:

- What is the accounting for the source of funds for State-Owned Commercial Banks (BUMN) in Denpasar City during the COVID-19 pandemic?

- What is the accounting for the management of funds for State-Owned Commercial Banks (BUMN) in Denpasar City during the COVID-19 pandemic?

The data obtained certainly has its own advantages and disadvantages, so it is necessary to analyze the data collected to obtain a more valid reality capture. The data analysis technique in this study uses an interactive model data analysis as developed by Miles, et. all (2014), namely data condensation, data display, and conclusion drawing / verification. This study uses an interactive model of data analysis to provide confidence about the validity of the data obtained, so that researchers do not hesitate in drawing conclusions on the research being conducted. The first process begins with data condensation, which is the process of sorting, giving away, and transforming all data derived from observations and interview transcripts that have been carried out while in the field. The second process, presenting data (data display) is a process of organizing and unifying information into more systematic points. Data presentation is done to help understand and provide an effective overall picture of information as a basis for making conclusions. The last process is a conclusion drawing from the results of condensation of data and presentation of the data.

\section{RESULTS OF STUDY}

Persero is a BUMN whose form of business is a limited liability company or PT. The majority of Persero's shares or the equivalent of $51 \%$ must be controlled by the government (Wikipedia, 2017). Persero is expected to be able to obtain large profits, so the company is automatically required to be able to provide the best goods and services so that the resulting output products continue to sell and continue to make profits. Organ Persero, namely directors, commissioners and rups or general meeting of shareholders. The characteristics of the Persero are as follows (Wikipedia, 2017):

- The minister to the president proposed the establishment of the company;

- The implementation of the establishment is carried out by the minister with due observance of legislation;

- Its status is in the form of a limited liability company regulated by law;

- The capital is in the form of shares;

- Part or all of the capital is owned by the state from the separated state assets;

- The organs of the company are the GMS, directors and commissioners;

- The appointed minister has the power to be the shareholder of the government;

- If all of the shares are owned by the government, then the minister acts as the GMS, if only partially, then as the shareholder of a limited liability company;

- The GMS acts as the highest authority of the company;

- Led by the board of directors;

- The annual report is submitted to the GMS for approval;

- Do not get state facilities;

- The main goal is to make a profit;

- Business relations are regulated in civil law.

A state-owned bank or a state-owned bank or often known as a government bank because the majority of its shares are owned by the government. In early 2000 the government restructured the banks due to the impact of the economic crisis. The stateowned banks, which originally had seven banks, were merged into 4 banks.

Bank BNI. PT. Bank Negara Indonesia (Persero) Tbk is a government bank in Indonesia. BNI is led by a President Director who currently is Gatot M. Suwondo. BNI is the oldest commercial bank in the history of the Republic of Indonesia. This bank was founded 
on July 5, 1946. Currently, BNI has 914 branch offices in Indonesia and 5 overseas. BNI also has a sharia banking unit. Established in 1946 and prepared to become a Circulation Bank or Central Bank responsible for issuing and managing the Indonesian currency. Several months after its establishment, Bank Negara Indonesia began circulating the first official payment instrument Oeang Republik Indonesia or ORI.

In 1955 the role of Bank Negara Indonesia shifted to become a development bank and later received the right to act as a foreign exchange bank. In line with the increase in capital in 1955, the status of Bank Negara Indonesia changed to become a commercial bank by juridical stipulation through emergency law No. 2 of 1955. In the same year Bank Negara Indonesia opened its first overseas branch, namely in Singapore (Wikipedia, 2017).

Bank BRI. Bank Rakyat Indonesia (BRI) is one of the largest state-owned banks in Indonesia. Initially, Bank Rakyat Indonesia (BRI) was founded in Purwokerto, Central Java by Raden Bei Aria Wirjaatmadja under the name De Poerwokertosche Hulp en Spaarbank der Inlandsche Hoofden or "Aid and Savings Bank Owned by Priyayi Purwokerto", a financial institution that serves national people. Indonesian (native). The institution was established on December 16, 1895, which was later used as the birthday of BRI. Based on law no. 14 of 1967 concerning the main banking law and law no. 13 of 1968 concerning the Central Bank Act, in essence, restoring the function of Bank Indonesia as the Central Bank and Bank Negara Indonesia Unit II for the Rular and Export-Import Sector, respectively, are separated into two banks, namely Bank Rakyat Indonesia and the Indonesian Export-Import Bank. Furthermore, based on Law no. 21 of 1968 re-established BRI's main tasks as a commercial bank. Since August 1, 1992 based on banking law No. 7 of 1992 and Government Regulation No. 21 of 1992 BRI status changed to a limited liability company. The ownership of $\mathrm{BRI}$ at that time was still $100 \%$ in the hands of the Government of the Republic of Indonesia. In 2003, the Indonesian government decided to sell $30 \%$ of the bank's shares, so that it became a public company with the official name PT. Bank Rakyat Indonesia (Persero) Tbk which is still in use today (Wikipedia, 2017). Since August 1, 1992 based on banking law No. 7 of 1992 and Government Regulation No. 21 of 1992 BRI status changed to a limited liability company. The ownership of BRI at that time was still $100 \%$ in the hands of the Government of the Republic of Indonesia. In 2003, the Indonesian government decided to sell $30 \%$ of the bank's shares, so that it became a public company with the official name PT. Bank Rakyat Indonesia (Persero) Tbk which is still in use today (Wikipedia, 2017). Since August 1, 1992 based on banking law No. 7 of 1992 and Government Regulation No. 21 of 1992 BRI status changed to a limited liability company. The ownership of BRI at that time was still $100 \%$ in the hands of the Government of the Republic of Indonesia. In 2003, the Indonesian government decided to sell $30 \%$ of the bank's shares, so that it became a public company with the official name PT. Bank Rakyat Indonesia (Persero) Tbk which is still in use today (Wikipedia, 2017).

Bank BTN. Bank Tabungan Negara or BTN is an Indonesian state-owned company in the form of a limited liability company and is engaged in banking financial services. Since 2000 , the bank has been led by lqbal Latanro as managing director. The forerunner of BTN began with the establishment of Postspaar bank in Batavia in 1897. In 1942, during the Japanese occupation of Indonesia, this bank was frozen and replaced with Tyokin Kyoku. After the proclamation of Indonesian independence this bank was taken over by the Indonesian government and changed to the Post Savings Office. The name and form of the company subsequently changed several times until finally in 1998 it was changed to the current official name and form (Wikipedia, 2017).

Mandiri Bank. Bank Mandiri was established on October 2, 1998 as part of the banking restructuring program implemented by the Indonesian government. In July 1999, four stateowned banks, namely, Bank Bumi Daya, Bank Dagang Negara, Bank Export Import Indonesia and Bank Pembangunan Indonesia, merged into Bank Mandiri. The history of the four Banks can be traced back more than 140 years. These four banks have helped shape the history of the development of the banking world in Indonesia.

Today, Bank Mandiri is the successor to a tradition of banking and financial services that has more than 140 years of experience. Each of the four banks joined to play an 
important role in economic development. After going through a long and very difficult preparation process, on July 14, 2003, Bank Mandiri finally listed its initial shares with the ticker code BMRI on the Jakarta Stock Exchange and Surabaya Stock Exchange. At the initial public offering, Bank Mandiri's shares were oversubscribed by more than 7 times. The process of investing in government shares in Bank Mandiri is based on government regulation No. 27 of 2003 concerning the sale of shares of the Republic of Indonesia to Bank Mandiri.

\section{DISCUSSION OF RESULTS}

Collection of Public Fund Sources at State-Owned Banks in Denpasar City Amid the COVID-19 Outbreak. Collecting public funds at state-owned banks in the city of Denpasar amid the COVID-19 pandemic has the same treatment, because basically state-owned banks are state-owned and are regulated by the POJK. There were a number of special rate rupiah deposits for customers at state-owned banks during the COVID 19 pandemic, namely rupiah special rate deposits to be given selectively, given as long as the quota was sufficient by confirming in advance to the Distribution Strategy Group or related units in each segment. Request for approval of Special Rate Rupiah Deposits to be accompanied by reasons and analysis of the proposed customer as well as ceiling availability data. The provision of rupiah special rate deposits takes precedence from fresh funds, which are given very selectively to maintain the cost of funds. Then the authority to give interest rates for each tier is determined by each segment. The provision of Special Rate Rupiah Deposits only applies to deposits with interest paid monthly and on maturity, not for deposits with prepaid interest. Special Rate Rupiah deposits that are due to be closely monitored, if a special rate will be given Back so that the branches of each BUMN bank immediately submit their approval at least 1 week before the due date to the authority holder in accordance with applicable regulations, where this Special Rate Discount applies since March 17, 2020 ago. In addition to the Rupiah Discount Special Rate for Deposits, there is also a Special Rate for USD Deposits, which is given as long as the quota is sufficient with prior confirmation to the Distribution Strategy Group or the related unit in each segment. Request for USD Special Rate Deposit to be completed with reasons and analysis of the proposed customer as well as data on the availability of the ceiling, the same as the Special Rate Rupiah Deposit, the preferred discount rate comes from fresh funds which are very selectively given to maintain cost funds. This discout rate is valid since March 8, 2020.

Following are the special rates and respective authorities. From several customers who were met at state-owned banks, said that some customers withdrew their deposits for their survival in the face of this pandemic. Because many customers have MSME businesses, where most of their income is from the tourism sector, while currently the tourism sector is still experiencing a decline. Tourists are not allowed to visit Bali, even though there are already several local tourists, but those who support the main income of MSME entrepreneurs are foreign tourists. Some of the customers who were less affected by the pandemic took the opportunity with the discount rate issued by state-owned banks. What's more, a concern is fresh funds, which are new deposit customers.

Distribution of Public Fund Sources to State-Owned Banks in Denpasar City amid the COVID-19 Outbreak. What has had the most impact on the spread of the COVID-19 outbreak is credit distribution, because negative large customers of state-owned banks are debtor customers. Therefore, the POJK issued a press release related to national economic stimulus as a countercyclical policy on the impact of the spread of coronavirus disease 2019 (POJK Stimulus Impact of COVID 19), namely POJK number 11 / POJK.03 / 2020 which contains:

1. The development of the spread of the coronavirus disease 2019 (COVID-19) has a direct or indirect impact on the performance and capacity of debtors including micro, small and medium business (MSME) debtors, thus potentially disrupting banking performance and stability. Therefore, in order to optimize the banking intermediation function, maintain stability, financial attention, and supporting economic growth 
requires economic stimulus policies as a countercyclical impact of the spread of COVID-19.

2. The main points of POJK regulation on the Stimulus of the Impact of COVID-19 include:

- This POJK applies to BUK, BUS, UUS, BPR, and BPRS;

- Banks can implement policies that support economic growth stimulus for debtors affected by the spread of COVID-19, including MSME debtors, while still paying attention to the principle of prudence;

- Debtors affected by the spread of COVID-19, including MSME debtors, are debtors who have difficulty fulfilling obligations to the Bank because the debtor or debtor's business is affected by the spread of COVID-19 either directly or indirectly in the economy, including tourism, transportation, hospitality, trade, processing, agriculture and mining.

3. The stimulus policy consists of:

- Assessment of the quality of credit / financing / other provision of funds is only based on the accuracy of principal and / or interest payments for credit / financing / other provision of funds with a ceiling of up to IDR 10 billion;

- Improvement of credit / financing quality to being restructured during the validity period of the POJK. This restructuring provision can be applied by the Bank regardless negative credit / financing ceiling or type of debtor.

4. The way of restructuring credit / financing is carried out as stipulated in the OJK regulations regarding quality assessment, among others by:

- Interest rate reduction;

- Extension of time;

- Reduction in principal arrears;

- Reduction in arrears of interest;

- Additional credit / financing facilities; and / or

- Conversion of credit / financing into Temporary Equity Participation.

5. Banks can provide new credit / financing / provision of funds to debtors who have received special treatment in accordance with this POJK by determining the quality of credit / financing / other provision of funds carried out separately from the quality of credit / financing / other previous provision of funds.

6. The Bank submits periodic reports on the application of this POJK for Supervisory monitoring since the position of the data at the end of April 2020.

7. This provision is valid from the time of promulgation until March 31, 2021.

So the government through state-owned banks held a credit restructuring where the underlying thing was POJK, and business credit was given a stimulus from the range of 0-10 billion. For People's Business Credit (KUR) a nominal value of 0-500 million rupiah and for commercial credit of 1-10 billion rupiah. The COVID-19 stimulus includes deferred principal and interest, where KUR 2018 gets 9\% deferred interest, 2019 KUR gets 7\% deferred interest and in 2020 gets 6\% deferred interest. Deferred is for the first three months, then a $3 \%$ interest subsidy for the next 3 months. The customer is given a choice, does not pay the principal and some pay only the principal. So, customers who borrow in 2020 get free interest, because of a subsidy from the government. This program is only for COVID-19 which is estimated to be until March 31, 2021. Business loans from the 500 million-10 billion figure last June are also planned to be given an interest subsidy. The amount of restructuring varies depending on the impact that COVID-19 has on the customer's business sector, the greater the impact of COVID, for example on the tourism sector, the greater the relief that the customer will get. Currently, state-owned banks are being selective; lending is only to the partner sector in terms of bailout payments, for example BPJS bailouts to hospitals and the trade sector while it is still in 'hold'

The restructuring is very beneficial for customers, especially those affected by COVID19. This makes it easier for customers to only pay interest or delay credit payments. Customers are also grateful for the policies made by the government regarding this outbreak, 
because many customers are facing the impact from COVID-19, even going out of business. However, there are some customers who still do not understand about government policies, especially debtor customers, many customers think that their credit is completely written off, in fact delaying credit payments is a different thing from write-offs. If the customer delays payment for 3 months, then the customer is allowed not to pay the credit for the next 3 months, but after that he will pay again as usual.

\section{CONCLUSION}

The COVID-19 pandemic has had a number of negative impacts on the world, especially Indonesia, which has been hit by the COVID-19 outbreak since March 2020. The impact caused by the spread of this virus has been felt by many people, one of which is banking, an institution that is obliged to collect and channel funds to the public. Therefore, POJK through banking institutions make rules regarding the collection and distribution of funds for BUMN Banks. For deposits through time deposits, several policies have been issued, namely rupiah special rate deposits to be given selectively, provided as long as the quota is sufficient and confirmed in advance to the Distribution Strategy Group or related units in each segment. The provision of rupiah special rate deposits takes precedence from fresh funds, which are given very selectively to maintain the cost of funds. Then the authority to give interest rates for each tier is determined by each segment.

\section{SUGGESTIONS}

State-owned banks and the government should provide an adequate understanding regarding restructuring, especially for credit, because many customers do not understand the meaning of this restructuring, resulting in miss communication between customers and banks. As we know, customers of state-owned banks are customers who have a low dominant educational background and do not know sufficient knowledge of how banking works.

In this study, only looking at the point of view of banking institutions and customers. Adequate qualitative research should be able to look deeper into the problems faced so as to produce new theories for academic interests. It is hoped that further research will be able to see it from a different perspective and perspective.

\section{REFERENCES}

1. Abidah, Atik. (2016). Fundraising Strategy Analysis for Improving ZIS Management at the Amil Zakat Institution, Ponorogo Regency. Kodifikasia, Vol. 10, No. 1, 163-189.

2. Afriyeni, A. Fernos, J (2018). Analysis of Determinants of Profitability Performance for Conventional Rural Banks (BPR) in West Sumatra. Benefita Journal: Development Economics, Business Management and Accounting. Volume 3. No. 3.

3. Assauri, Sofjan. (2011). Strategic Management: Sustainable Competitive Advantage. Jakarta: Management Institute Publishers.

4. Baridwan, Zaki. Dr. M. Sc., Accountant, 2000, Intermediate Accounting, Yogyakarta: BPFE.

5. Dehotman, K. (2016). The Effect of Education on Employee Performance at Baitul Mal Wat-Tamwil in Riau Province. JEBI (Journal of Islamic Economics and Business), 1 (2): 217-234.

6. Dehotman, K., \& Yusrialis, Y. (2016). Challenges for the Development of Baitul Mal WatTamwil in Pekanbaru Riau. Maqdis: Journal of Islamic Economic Studies, 1 (2): 189-20

7. Hidayar, Gatot. Deswanti, Shinta. Goenawan (2012). Community Fund Collection and Distribution System at Bri Unit Manda. Journal of Accounting and Finance. Vol. 3 No. 1, 107-122.

8. Ismail, Drs.MBAAK, (2010). Bank Accounting: Theory and Application in Rupiah. Gold. Jakarta. 
9. Khasanah, Umrotul. (2010). Modern Zakat Management: An Instrument for Empowering the Economy of the People. Malang: UIN-MALIKI PRESS.

10. Latumaerissa, JR (2011). Banks and Other Financial Institutions. Jakarta: Four Salemba.

11. Marlius, D. (2018). Customer Loyalty of Bank Nagari Syariah Bukittinggi Branch Viewed From Service Quality. Journal of Pundi. Volume 1. No. 3, 12-22.

12. Martono, (2010) Banks and Other Financial Institutions, ECONOSIA, Faculty of Economics, UII, Yogyakarta.

13. Mulyana, Deddy. (2018). Qualitative Research Methodology: A New Paradigm of Communication and Other Social Sciences. Bandung: PT REMAJA ROSDAKARYA.

14. Saib, K. (2016). Sustainability of Micro Credit Agencies in Building Small Traders: Baitul Mal Wat-Tamwil in Riau Province. JEBI (Journal of Islamic Economics and Business), 1 (1): 17-32.

15. Sanwani (2017). Strategy for Collection and Distribution of Funds at Baitul Mal Wat Tamwil. Journal of Financial Institutions and Banking. Vol. 2 No. 1.

16. Sugiyono (2014). Combined Research Methods (Mixed Methods). Bandung: Alfabeta.

17. Supeno, Wangsit (2017). Analysis of Fundraising Performance in Increasing Credit Distribution at Rural Banks. Monetary Journal Vol IV No.2: 121-131.

18. (2019). Bank Accounting: Theory and Application in Rupiah. Golden. Jakarta. 